\title{
Solid Particle Erosion Behavior of Carbon Fiber - Metal Wire Hybrid Reinforced Polymer Composites
}

\author{
Gürkan ARSLAN ${ }^{1}$, Sinan FIDAN ${ }^{2}$, Tamer SINMAZÇELIK ${ }^{3}$
}

1Kocaeli University, Institute of Science, Aviation Knowledge and Technology, 41380, Kocaeli, Turkey

2 Kocaeli University, Faculty of Aeronautics and Astronautics, Department of Airframe \& Powerplant, 41285, Kartepe-Kocaeli, Turkey

3 Kocaeli University, Faculty of Engineering, Department of Mechanical Engineering, 41380, Kocaeli, Turkey e-mail: gurkanarslan1071@gmail.com

\begin{abstract}
Carbon fiber reinforced composite materials (CFRP) are being widely used in aircraft parts and unmanned air vehicle (UAV) airframe production due to their high specific stiffness and strength. Besides their superior characteristics, they have a disadvantage of poor electrical conductivity when used in UAV airframes which subjected to lightning strike during their service life. In order to protect UAV airframe from lightning strike damage, adding a metal wire to CFRP composite is an alternative method. Moreover, UAV and aircraft airframe materials subjected to solid particle erosion damage during their service life also.Surface damage induced by solid particle erosion cause aerodynamic losses and result with increase in specific fuel consumption or shortening of maximum air vehicle range. Also worn body could be lost its lightning strike residence. It is evident that there is no much literature study about CFRP - metal wire hybrid reinforced composites solid particle erosion behavior. The aim of this study is to characterize the solid particle erosion behavior of CFRP metal wire hybrid reinforced composite and analyze the post wear damage induced in the surface of the samples. Solid particle tests were performed according to ASTM G 76 standard in a specially designed test rig.Mass loss and erosion rate measurements after tests were done and damage mechanisms were discussed. Surface roughness analysis of specimens before and after solid particle erosion tests were performed by using 3D non-contact laser profilometer.
\end{abstract}

Key Words: Solid particle erosion, Carbon fiber-metal wire hybrid reinforced composite,Unmanned air vehicle

\section{Karbon Fiber-Metal Tel Örgü Hibrit Kompozitlerin Katı Partikül Erozyonu Davranışları}

\begin{abstract}
Özet: Karbon fiber güçlendirilmiş kompozitler hava araçlarının parçalarında ve insansız hava araçlarının (İHA) gövde yapılarında yüksek fiziksel özellikleri ve mekanik dayanıklılıklarından dolayı sıklıkla kullanılmaktadır.Bu üstün özelliklerinin yanında yıldırıma maruz kalmış bir İHA da yetersiz elektrik iletkenliği gösterirler.Karbon fiber güçlendirilmiş kompozitlere metal bir tel örgü eklemek İHA gövde yapılarını yıldırım hasarından korumak için alternatif bir yöntemdir.Diğer yandan İHA ve hava aracı gövde yapıları servis süreleri boyunca katı partikül erozyonuna da maruz kalırlar.Katı partikül erozyonunundan kaynaklanan yüzey hasarları aerodinamik kayıplara dolayısıyla yakıt tüketiminin artmasına ve hava araçlarının menzilinin kısalmasına sebep olur.Aynı zamanda hasarlı kısımlar yıldırım direncinin de azalmasına sebep olacaktır.Literatürde karbon fiber-metal örgü hibrit güçlendirilmiş kompozitlerin katı partikül erozyonuyla ilgili yeterli sayıda çalışma yoktur.Bu çalışmanın amacı bu kompozitlerin katı partikül erozyonu davranışlarını karakterize etmek ve numune yüzeylerinde oluşan aşınma hasarını analiz etmektir.Katı partikül testleri ASTM G 76 standartlarına göre dizayn edilmiş test düzeneklerinde yapılmıştır. Testlerden sonra ağırlık kaybı ve erozyon ölçümleri yapılmış, hasar mekanizmaları tartışılmıştır.Katı partikül testlerinden önceki ve sonraki numunelerin yüzey pürüzlenmesinin analizi temassız üç boyutlu lazer profilometre kullanılarak yapılmıştır.
\end{abstract}

Anahtar Kelimeler: Katı Partikül Erozyonu,Karbon Fiber-Metal Örgü Hibrit Kompozit İnsansız Hava Arac1

\footnotetext{
How to cite this article

Arslan G., Fidan S.,Sınmazçelik T.,"Solid Particle Erosion Behavior Of Carbon Fiber - Metal Wire Hybrid Reinforced Polymer Composites” El-Cezerî Journal of Science and Engineering, 2018, 5(1); 182-190 


\section{Introduction}

Solid particle erosion involves the impact of small high speed particles on a target, causing surface damage and material removal that, on a per particle basis, occurs on a very small scale and for a very short time. This, together with the irregularity of particle shape and size typically found in erodent powders, and the complexity of the deformation and damage behavior of materials under impact loadings, makes it very challenging to identify the micro- mechanisms of erosion that lead to macro-scale material loss. These complexities have led researchers to take simplified approaches in order to understand erosion mechanisms in ductile materials[1].

The introduction of composites in the primary structure of modern aircraft presents special problems with regards to the lighting strike threat. While metallic structures such as traditional aluminum airframes are highly conductive, Carbon Fiber Reinforced Polymers (CFRP) have a much lower electrical conductivity. Although carbon fibers are good conductors, the polymer matrix is an excellent dielectric and therefore reduces the overall conductivity of the composite laminate. When lightning strikes, a large amount of energy is delivered very rapidly, causing the ionized channel to expand with supersonic speed. If the shockwave encounters a hard surface, its kinetic energy is transformed into a pressure rise, which causes fragmentation of the structure [2]. At the same time, resistive heating leads to temperature rise and, in turn, it initiates a breakdown of the resin by pyrolysis. If the gases developing from the burning resin are trapped in a substrate, explosive release may occur with subsequent damage to the structure [2][3][4]. In order to reduce the threat of lightning strike damage, a lightning strike protection (LSP) is typically utilized. A commonly utilized LSP is a metallic wire mesh, which is placed on the outer surface of the CFRP structure, and acts as a continuously-conductive outer layer to dissipate direct or indirect electromagnetic interference effects. The mesh can be comprised of aluminum, cop- per or bronze wire, and can either be co-woven with the carbon fiber in a prepreg fabric ply, or bonded separately as the outermost laminate layer [2-5].

Solid particle erosion primary damage mechanism is removing material from surface and inducing roughness. Since outer layer of CFRP - metal wire hybrid reinforced composite consist of metal wire to accomplish lightning strike protection, the repeated impacts of abrasive particles may cause wire damage and decrease the capability of protection. Hence, the examination of solid particle erosion damage mechanism in CFRP - metal wire hybrid reinforced composite used for lightning strike protection is crucial. The aim of this study is to characterize the solid particle erosion behavior of CFRP - metal wire hybrid reinforced composite and analyze the post wear damage induced in the surface of the samples.

\section{Methods}

CFRP - metal wire hybrid reinforced composite is used in solid particle erosion tests. The samples were cut into square coupon test samples, with a dimension of $40 \mathrm{~mm} \times 40 \mathrm{~mm}$. Carbon fiber fabric with an aerial weight of $300 \mathrm{gr} / \mathrm{m}^{2}$ and $+45 /-45$ biaxial fiber orientation was used in manufacturing samples. Nominal thickness of carbon fiber fabric is $0,3 \mathrm{~mm}( \pm \% 15)$. Epikote Resin MGS L 285 was used as composite resin. The technical properties of Epikote Resin MGS L 285 was given in Table 1, according to the manufacturer's declaration. A metal wire fiber laminate with a square mesh geometry was applied to the outer side of the test samples. 
Table 1. Epikote Resin MGS L 285 properties

\begin{tabular}{|c|c|}
\hline Certificate & German Federal Aviation \\
\hline Usage Area & $\begin{array}{c}\text { Glider airframe, aircraft, UAV, model } \\
\text { aircraft }\end{array}$ \\
\hline Service Temperature & $\begin{array}{c}-60^{\circ} \mathrm{C} /+50^{\circ} \mathrm{C} \text { without heat treatment } \\
-60^{\circ} \mathrm{C} / 80^{\circ} \mathrm{C} \text { with heat treatment }\end{array}$ \\
\hline Process Temperature & $+10^{\circ} \mathrm{C} / 50^{\circ} \mathrm{C}$ \\
\hline Properties & $\begin{array}{c}\text { Very high level compatibility } \\
\text { Good mechanical and thermal properties } \\
\text { Running time from } 45 \text { minutes to } 4 \\
\text { hours }\end{array}$ \\
\hline Storage & 24 months in package \\
\hline
\end{tabular}

In manufacturing composite, EPIKURE Curing Agent MGS H 285 is used. The technical properties of EPIKURE Curing Agent MGS H 285 was given in Table 2, according to the manufacturer's declaration.

Table 2. EPIKURE Curing Agent MGS H 285 properties

\begin{tabular}{|c|c|}
\hline Density $\left(\mathrm{gr} / \mathrm{cm}^{3}\right)$ & $0,94-0,97$ \\
\hline Viscosity (mPas) & $50-100$ \\
\hline Amine Value (mgr KOH/gr) & $480-550$ \\
\hline Refractor index & $1,5020-1,5500$ \\
\hline Measuring Temperature & $25^{\circ} \mathrm{C}$ \\
\hline
\end{tabular}
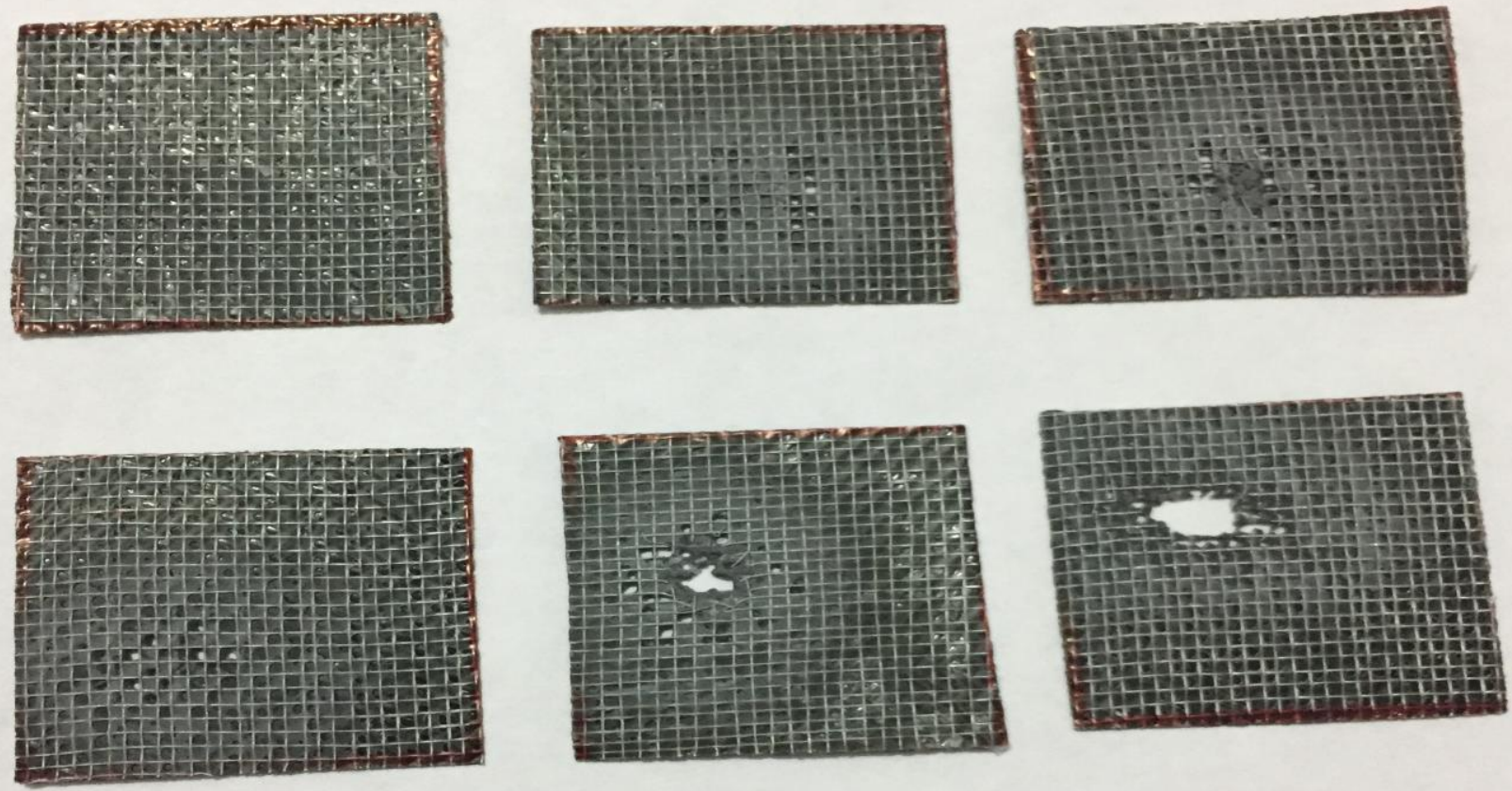

Figure.1 Test coupons after erosions tests

Solid particle erosion tests were performed in accordance with the ASTM G76 standard. The 80 mesh $(150-212 \mu \mathrm{m})$ alumina particles are used as an erodent during the solid particle erosion tests. The particle erosion tests were performed at six different impact angles $\left(15^{\circ}, 30^{\circ}, 45^{\circ}, 60^{\circ}, 75^{\circ}\right.$, $90^{\circ}$ ). Erosive particles are blasted under air pressure of 3 bar through a ceramic nozzle with an inner diameter of $7 \mathrm{~mm}$ in a specially designed air jet test rig. CFRP - metal wire hybrid reinforced 
composite samples were located at a distance of $20 \mathrm{~mm}$ from the nozzle exit (stand-off distance). Abrasive blasting was continued for 10 seconds in each test. Three reputations were carried out for each test parameter. The mean value of three experiments was taken into account for every test condition. The erosion rates calculated from mass loss and used erodent was presented. Before the particle erosion tests, sample surfaces were cleaned with air blasting and acetone in order to achieve clean surface. Mass loss was measured by using an electronic balance with an accuracy of $\pm 0,1 \mathrm{mg}$.

The erosion test rig used in this study is illustrated in Fig 2. Accelerated particles were impacted the sample surface, which can be located at desired distance from nozzle and placed at various impingement angles $\left(15^{\circ}-90^{\circ}\right)$ by adjustable sample holder shown in Fig 2 . Particle impact velocity was measured by using the double disc method. Under 3 bar air blast pressure; abrasive alumina particles with a size of 80 mesh has an impact velocity of $72 \mathrm{~m} / \mathrm{s}$.

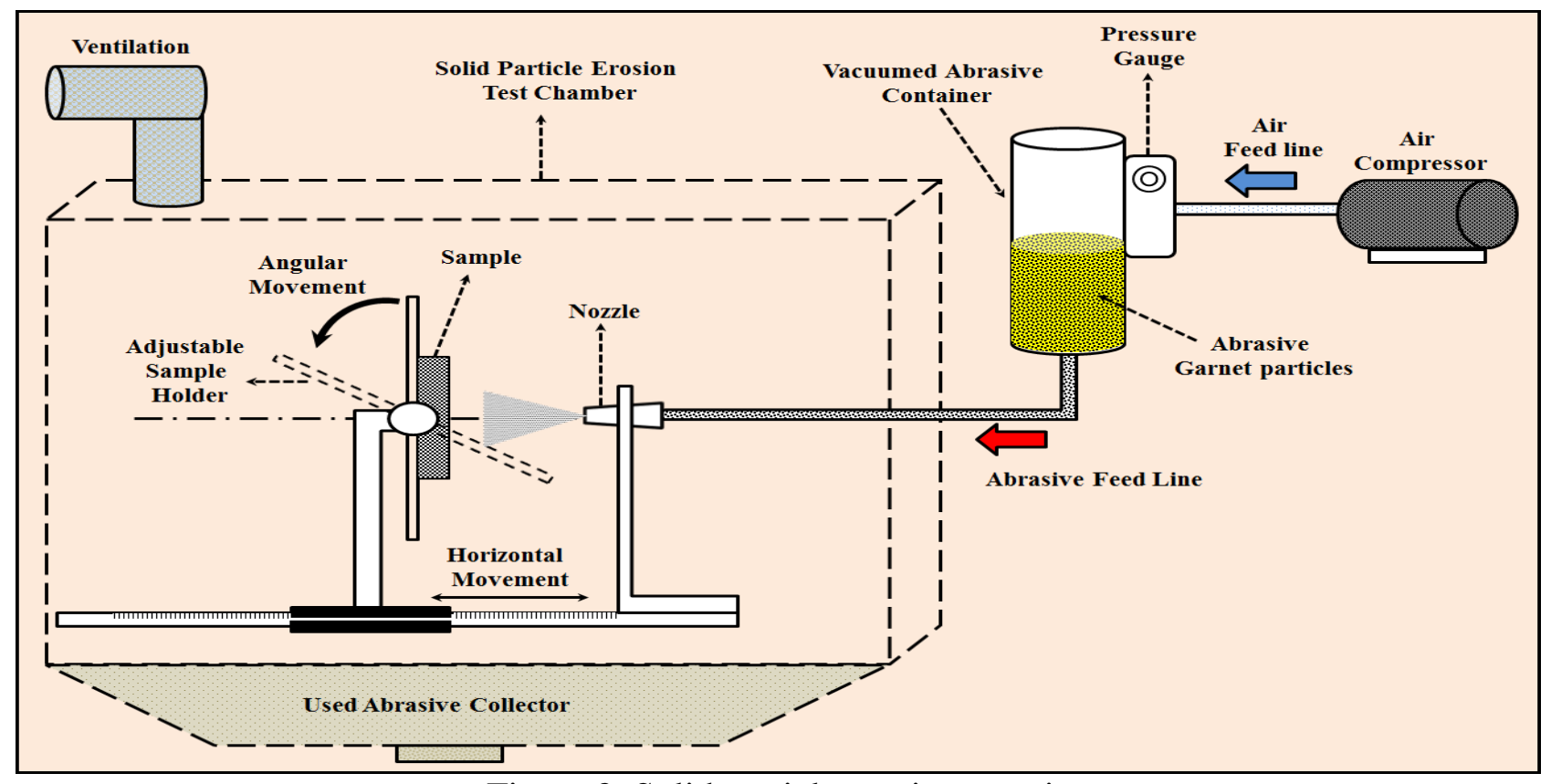

Figure 2. Solid particle erosion test rig

Solid particle erosion test parameters are given in Table 3.

Table 3 : Solid particle erosion test parameters

\begin{tabular}{|c|c|}
\hline Erodent type & Alumina \\
\hline Erodent size & $80 \mathrm{mesh}(150-212 \mu \mathrm{m})$ \\
\hline Particle impingement angle & $15^{\circ}, 30^{\circ}, 45^{\circ}, 60^{\circ}, 75^{\circ}, 90^{\circ}$ \\
\hline Acceleration/blast gun pressure & $3 \mathrm{bar}$ \\
\hline Erodent velocity & $80 \mathrm{mesh}(72 \mathrm{~m} / \mathrm{s})$ \\
\hline Erodent Flow Rate & $17 \mathrm{gr} / \mathrm{s}$ \\
\hline Test temperature & $25^{\circ} \mathrm{C} \pm 2{ }^{\circ} \mathrm{C}$ \\
\hline Stand-off Distance & $20 \mathrm{~mm}$ \\
\hline Humidity & $50 \%$ \\
\hline
\end{tabular}

After solid particle erosion tests, the surfaces of the test samples were scanned with Nanovea PS50 non-contact 3D profilometer. The erosion crater area of $20 \mathrm{~mm} \times 20 \mathrm{~mm}$ scanned with a $20 \mu \mathrm{m}$ precision. Roughness measurements and related results were obtained from these scans. Roughness parameters such as $R_{a}, R_{v}, R_{z}, S_{a}$ and erosion crater volume were discussed. 


\section{Findings}

The erosion rate of a material is defined by the weight loss of the target material (mg) divided by the weight of the erodent particles impinged on the target surface during erosion time $(\mathrm{g})$. Erodent flow rate of tests were measured as $17 \mathrm{gr} / \mathrm{s}$ and test duration was 10 seconds. Hence, the erosion rate calculation is accomplished by dividing the mass loss of each sample by 170 . the results also multiplied by 1000 in order to use a scientific scale in graph.

Figure 3 illustrates the erosion rate of CFRP - metal wire hybrid reinforced composite tested with 80 mesh alumina abrasive particles at six impact angles. At oblique angles such as $15^{\circ}, 30^{\circ}$ and $45^{\circ}$; erosion rate increases by increasing impact angle. Due to semi-ductile nature of CFRP, maximum erosion rate observed at $45^{\circ}-60^{\circ}$ in these type composites [6]. On the other hand, CFRP - metal wire hybrid reinforced composite tested in this work also contains metal wires and this resulted with the maximum erosion rate occurrence at $45^{\circ}$ impact angle. At impact angles $60^{\circ}, 75^{\circ}$ and $90^{\circ}$; the erosion rate decreases when compared with $15^{\circ}, 30^{\circ}$ and $45^{\circ}$. Minimum erosion rate observed at $75^{\circ}$ impact angle. The surface topography of the composite is not a homogenous character; the erosion rate evaluations must also be discussed in a hybrid model damage characterization.

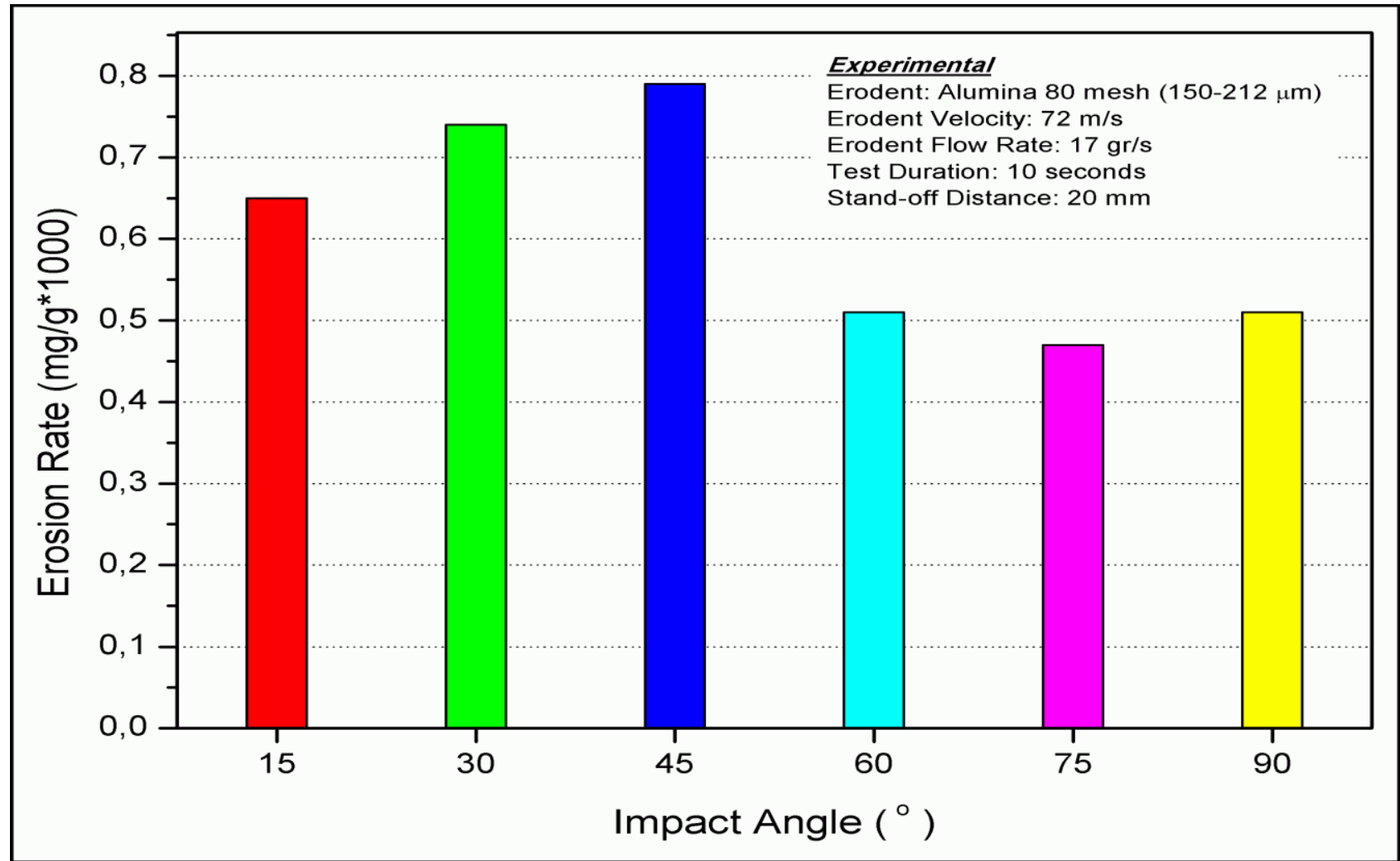

Figure 3. CFRP - metal wire hybrid reinforced composite erosion rates versus impact angle

Figure 4 illustrates the 3D surface roughness maps of CFRP - metal wire hybrid reinforced composite tested with 80 mesh alumina abrasive particles. Surface scanning with laser profilometer gives the average roughness of surface named $S_{a}$.

In Figure 4, erosion crater surface region boundaries were clearly be seen with 3D surface maps. At oblique angles $\left(15^{\circ}, 30^{\circ}\right.$ and $\left.45^{\circ}\right)$ the carbon fiber and metal wire effected by abrasive particle bombardment and the damage zones with material removal can be clearly seen in 3D surface topography images taken by non-contact laser profilometer. At $45^{\circ}$ impact angle (figure 4-c) erosion crater spread over the sample surface. Both the carbon reinforcement and metal wire removed and disconnection between individual metal wires occurred. The disconnection of metal 
wires will make lightning protection system useless and unserviceable. At normal impact angle $\left(90^{\circ}\right)$, although the carbon fiber region removed, the metal wires except center erosion region has no mass removal and disconnection.



Figure 4. 3D surface roughness maps of CFRP - metal wire hybrid reinforced composite eroded at six impact angles (a) $15^{\circ}$ (b) $30^{\circ}$ (c) $45^{\circ}$ (d) $60^{\circ}$ (e) $75^{\circ}$ (f) $90^{\circ}$.

Figure 5 illustrates the line roughness of CFRP - metal wire hybrid reinforced composite tested with 80 mesh alumina abrasive particles taken from the center of the tested samples. On the left, the location of the line illustrated on the surface of the test coupons and on the right side, the roughness profile was shown in thickness axis.

In Figure 5-a, the erosion crater center line of CFRP - metal wire hybrid reinforced composite test samples eroded at $45^{\circ}$ impact angle through the thickness cross-section was seen. On the center region a wide material removal volume can be seen clearly. As the center region has no peaks, not only the CFRP but also the metal wires removed away from the test coupon by abrasive particle bombardment. This result is well-suited with the erosion rates because also maximum erosion rate observed at $45^{\circ}$ impact angle.

In Figure 5-b, the erosion crater center line of CFRP - metal wire hybrid reinforced composite test samples eroded at $75^{\circ}$ impact angle through the thickness cross-section was seen. Minimum erosion rate observed at $75^{\circ}$ impact angle. Hence, the center region of erosion crater at $75^{\circ}$ is not as dominant as it was in $45^{\circ}$. Material removal is very slight at $75^{\circ}$ when compared with $45^{\circ}$ crosssectional view. 


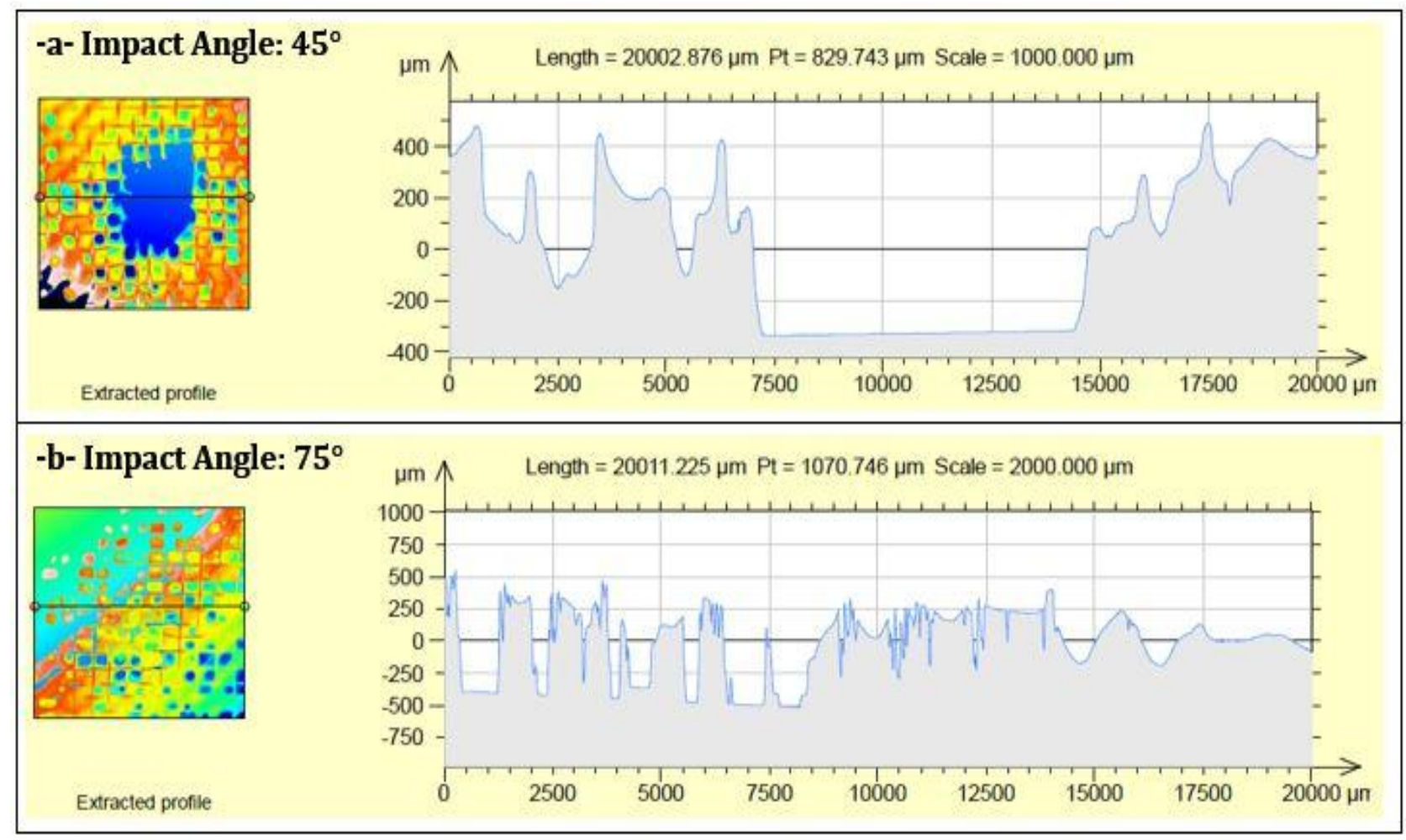

Figure 5. Surface roughness center profiles of CFRP - metal wire hybrid reinforced composite after erosion tests (a) $45^{\circ}$ (b) $75^{\circ}$

Figure 6 illustrates various roughness parameters such as $R_{a}, R_{v}, R_{z}$ and $S_{a}$ of CFRP - metal wire hybrid reinforced composite tested with 80 mesh alumina abrasive particles. As it can be seen in Figure 6 , maximum $R_{z}$ values measured at $60^{\circ}$ and $75^{\circ}$ impingement angles. $R_{z}$ implies the average of vertical distance between top of the peaks and bottom of the valleys occurred in sample surfaces after solid particle erosion tests. This result well-suited with the erosion rate results because the deformations at $60^{\circ}$ and $75^{\circ}$ increase roughness whilst slight material removal occurred. On the other hand, minimum $\mathrm{R}_{\mathrm{z}}$ measured at $45^{\circ}$ impact angle because of full material removal region at the bottom of central erosion crater. Similar results measured for $R_{a}$ and $R_{v}$ values like $R_{z}$. Maximum $R_{a}$ and $R_{v}$ values measured at $60^{\circ}$ and $75^{\circ}$ impact angles whilst minimum measured at $45^{\circ} . R_{a}$ value implies the average roughness of tested samples. $R_{v}$ implies the roughness values in valley occurred in sample surfaces after solid particle erosion tests. $S_{a}$ value implies average roughness of whole tested sample. Minimum $S_{a}$ value measured at $90^{\circ}$ impingement angle. Other impingement angles $S_{a}$ values are similar to each other. 


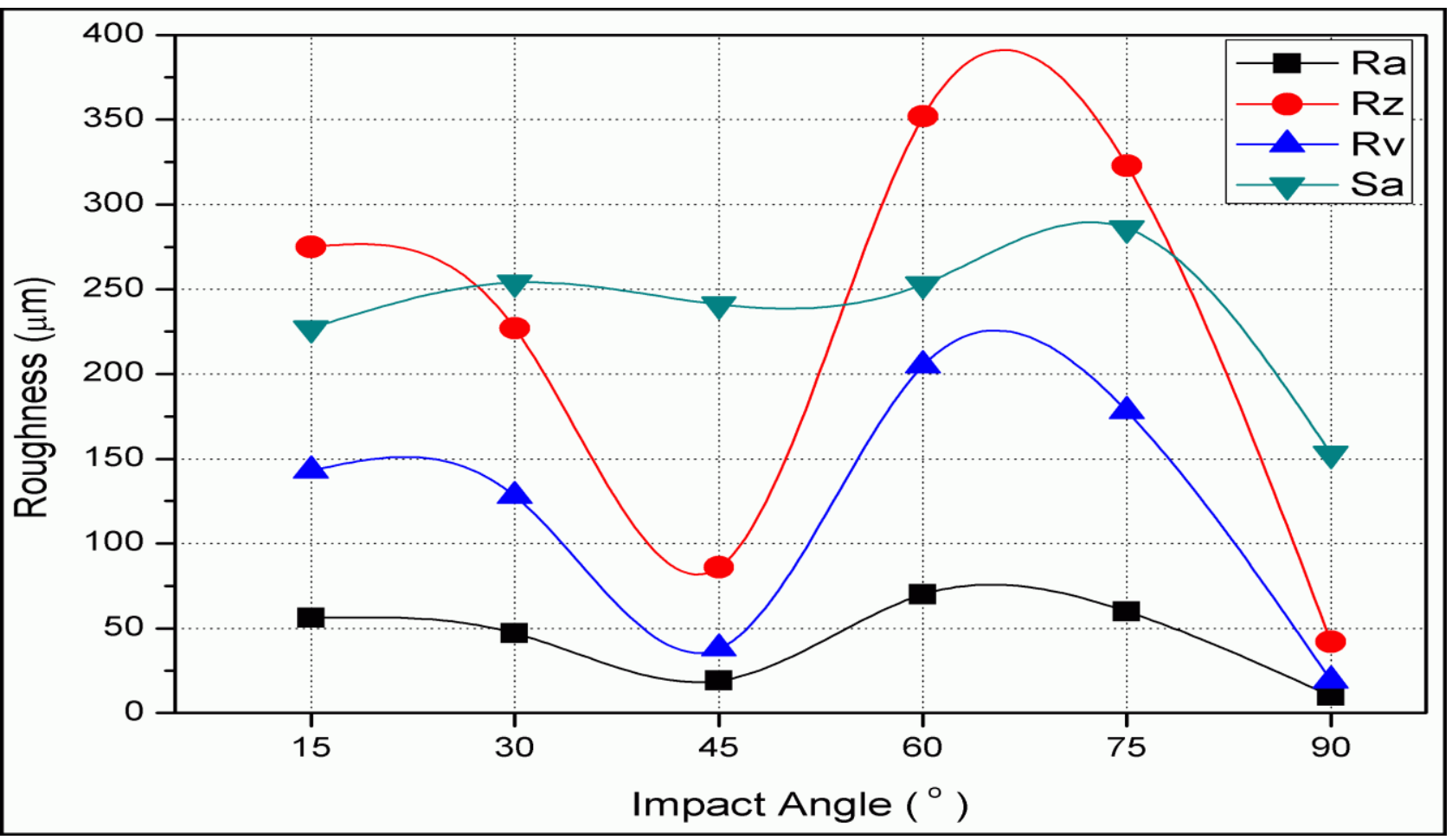

Figure 6. Roughness values of CFRP - metal wire hybrid reinforced composite eroded at six impact angles

Figure 7 illustrates erosion crater volumes of CFRP - metal wire hybrid reinforced composite tested with 80 mesh alumina abrasive particles. As seen in Figure 7, biggest erosion crater volume occurred at $45^{\circ}$ impingement angle. Main reason of maximum erosion crater at $45^{\circ}$ impingement angle is the crucial material removal from sample surface. At $45^{\circ}$ impact angle, measured erosion crater volume is approximately twice the volumes measured at $15^{\circ}, 30^{\circ}, 75^{\circ}$ and $90^{\circ}$. Minimum erosion crater volume measured at $90^{\circ}$ impact angle.

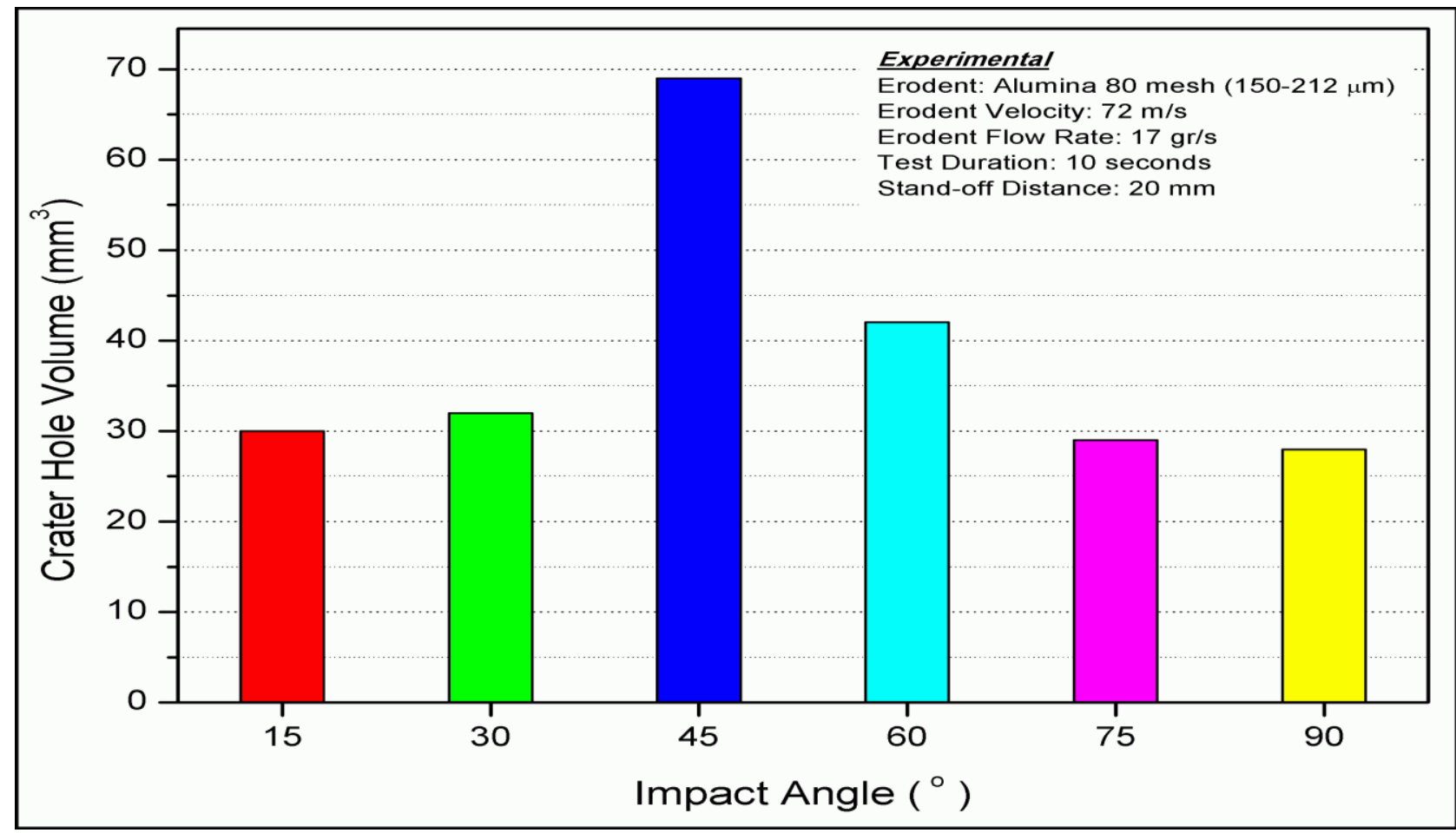

Figure 7. Erosion crater volume of CFRP - metal wire hybrid reinforced composites at six impact angles. 


\section{Results and Discussions}

The main conclusions drawn from the present work can be summarized as follows:

CFRP - metal wire hybrid reinforced composites eroded with 80 mesh alumina abrasive particles have minimum erosion rate at $75^{\circ}$ impingement angle whilst samples eroded at $45^{\circ}$ impingement angle. Hence, CFRP - metal wire hybrid reinforced composites dominant erosion mechanism work in a semi-ductile manner.

After erosion tests of CFRP - metal wire hybrid reinforced composites, roughness comparison was accomplished. Minimum $R_{a}, R_{v}$ and $R_{z}$ values are observed at $45^{\circ}$ impingement angle while maximum roughness values measured at $60^{\circ}$ and $75^{\circ}$ impact angles. $\mathrm{S}_{\mathrm{a}}$ value is similar at oblique angles while minimum $S_{a}$ measured at $90^{\circ}$ impingement angle.

Biggest erosion crater volume occurred at $45^{\circ}$ impingement angle. Hitting of abrasive particles at $45^{\circ}$ to CFRP - metal wire hybrid reinforced composites cause severe damage and material removal. Hence, lightning protection mission will be fail after a bombardment of abrasive particles at $45^{\circ}$ impingement angle.

\section{References}

[1] M. Takaffoli and M. Papini, "Numerical simulation of solid particle impacts on Al6061-T6 Part II: Materials removal mechanisms for impact of multiple angular particles," Wear, 2012, vol. 296, no. 1-2, pp. 648-655,

[2] H. Kawakami and P. Feraboli, "Lightning strike damage resistance and tolerance of scarfrepaired mesh-protected carbon fiber composites," Compos. Part A Appl. Sci. Manuf., vol. 42, no. 9 , pp. 1247-1262, 2011.

[3] E. Rupke, "Lightning direct effects handbook," Rept. AGATE-WP3.1-031027-043-Design Guidel., 2002.

[4] FAA, "DOT/FAA/CT-89/22 Aircraft Lightning Protection Handbook," Fed. Aviat. Adm., no. September, 1989.

[5] D. Tolerance and M. Workshop, "Damage Tolerance and Maintenance," Composites, 2006.

[6] S. Arjula, A. P. Harsha, and M. K. Ghosh, "Erosive wear of unidirectional carbon fibre reinforced polyetherimide composite," Mater. Lett., vol. 62, no. 17-18, pp. 3246-3249, 2008. 